\title{
PROSES IMPLEMENTASI MANAJEMEN KUALITAS
}

\author{
ARIEF RAHMANA, ${ }^{1}$ INDRYATI SUNARYO,${ }^{2}$ DRADJAD IRIANTO,${ }^{3}$ DAN UBUH BUCHARA HIDAJAT \\ Jurusan Teknik Industri, Universitas Widyatama, Bandung \\ 2,3,4 Program Studi Teknik Industri, Fakultas Teknologi Industri, ITB \\ E-mail: arief.rahmana@widyatama.ac.id
}

\begin{abstract}
ABSTRAK
Penelitian ini dilakukan untuk mempelajari proses penerapan manajemen kualitas, yang terdiri dari tiga tahap yaitu pengenalan, adopsi dan adaptasi. Penelitian strategi dalam penelitian ini adalah penelitian studi kasus di Perusahaan X, yang merupakan perusahaan yang sudah memiliki kemampuan untuk mengekspor dan bersertifikat sistem penjaminan kualitas. Metode pengumpulan data terstruktur wawancara dengan direktur, manajer, supervisor, dan karyawan Perusahaan X. Hasil penelitian menunjukkan bahwa pada tahap pengenalan ditunjukkan oleh pengakuan pelanggan tentang kualitas produk, Perusahaan X mulai mengekspor, dan permintaan dari pelanggan asing untuk kualitas sistem jaminan. Pada tahap adopsi ditunjukkan oleh rencana perusahaan untuk sertifikasi sistem jaminan kualitas, sertifikasi sistem jaminan kualitas, dan peningkatan kualitas. Sementara itu, dalam tahap adaptasi ditunjukkan oleh sertifikasi ulang sistem jaminan kualitas, peningkatan sistem jaminan kualitas, dan evaluasi proses produksi. Mereka memberikan wawasan bahwa Perusahaan X telah melakukan peningkatan kualitas berkelanjutan melalui penerapan manajemen mutu dengan tujuan untuk meningkatkan kepuasan pelanggan.
\end{abstract}

Kata kunci: implementasi, manajemen kualitas, pengenalan, adopsi, adaptasi

\begin{abstract}
This research is carried out to study implementation process of quality management, which consists of three stages namely introduction, adoption, and adaptation. Research strategy in this research is case study research in Company $X$, which is a company that already has the ability to export and certified quality assurace system. Prime method of collecting data is structured interview with director, managers, supervisors, and employees Company X. The result indicate that in the introduction stage are shown by customer recognition of quality product, Company X began to export, and demand of foreign customer to quality assurance system. In the adoption stage are shown by company's plan for certification of quality assurance system, certification of quality assurance system, and quality improvement. Meanwhile, in the adaptation stage are shown by recertification of quality assurance system, upgrading of quality assurance system, and production process evaluation. Those result give insight that Company $X$ has carried out continuous quality improvement through quality management implementation with the aim to enhance customer satisfaction.
\end{abstract}

Key words: implementation, quality management, introduction, adoption, adaptation

\section{PENDAHULUAN}

Implementasi manajemen kualitas dan program peningkatan kualitas dalam sebuah organisasi memiliki beberapa keuntungan di antaranya adalah dapat meningkatkan kepuasan pelanggan, meningkatkan kesadaran karyawan akan kualitas, meningkatkan kinerja organisasi, dan mencapai efektivitas organisasi (Irianto, 2005). Keuntungankeuntungan tersebut sangatlah penting bagi semua perusahaan, terutama di negara berkembang, seperti Indonesia, di mana level kualitas relatif rendah dan perlu untuk terus ditingkatkan sebagai landasan untuk menjalin kerjasama yang efektif antar perusahaan.

Manajemen kualitas dapat didefinisikan sebagai berikut: "All activities of the overall management function that determine the quality policy, objective, and responsibilities, and implement them by means such as quality planning, quality control, quality assurance, and quality improvement within quality system" (Zhang, 2000). Manajemen kualitas yang baik adalah mengintegrasikan perhatian pada kualitas produk, fokus pada konsumen, dan orientasi pada karyawan dengan menyediakan pendekatan integral dengan isu-isu organisasi (Damayanti. 2005) Berdasarkan persepsi tersebut, maka manajemen kualitas didefinisikan sebagai kreasi dari sistem organisasi, di mana ketika dipergunakan oleh anggota organisasi, dapat membimbing mereka untuk meningkatkan nilai produk atau jasa kepada konsumen. 
Manajemen kualitas mengalami evolusi yang dimulai dari kualitas inspeksi (inspection quality), pengendalian kualitas (quality control), penjaminan kualitas (quality assurance), sampai dengan manajemen kualitas total (total quality management). Total Quality Management (TQM) merupakan proses untuk mengelola kualitas; sebuah filosofi yang menekankan pada perbaikan dalam segala hal, yang terdiri atas sejumlah prinsip dan merupakan fondasi untuk melakukan perbaikan berkelanjutan (Rampersad, 2005).

Pendekatan yang digunakan dalam konsep manajemen kualitas adalah pendekatan sistem. Manajemen kualitas tidak hanya terdiri dari sistem nilai, melainkan didukung oleh teknik dan alat (Hansso, 2003). Implementasi manajemen kualitas berkaitan dengan manajemen perubahan organisasi, sehingga diperlukan tahapan untuk menerapkannya di perusahaan. Tahapan implementasi terdiri dari beberapa langkah yaitu pembentukan komitmen, penentuan tujuan, pengembangan misi, pemahaman proses, pemilahan proses (breaking down), monitoring, dan penyesuaian (Oakland, 1995). Pendapat lain mengatakan bahwa tahapan implementasi manajemen kualitas terdiri dari tahap pemahaman konsep dan filosofi, tahap persiapan dan perencanaan, tahap implementasi, dan tahap evaluasi (Taylor, 1996).

Irianto (2005) mengidentifikasi tiga tahap untuk implementasi manajemen kualitas, yaitu tahap inisiasi, tahap adopsi, dan tahap adaptasi. Tahap inisiasi juga dapat didefinisikan sebagai tahap introduksi, yaitu tahap di mana pimpinan perusahaan mulai mengenal dan memahami konsep manajemen kualitas sebelum akhirnya berkomitmen untuk mengimplementasikannya di perusahaan. Tahap adopsi sejalan dengan persiapan dan perencanaan, termasuk pengembangan misi. Tahap adaptasi meliputi monitoring, penyesuaian dan perbaikan. Pada penelitian ini, tahapan implementasi mengadopsi konsep yang digunakan oleh Irianto (2005), yang terdiri atas tahap introduksi, adopsi, dan adaptasi.

\section{METODE}

Model penelitian yang digunakan dalam mengkaji proses implementasi manajemen kualitas tersaji pada Gambar 1. Berdasarkan model yang tersaji pada Gambar 1 tersebut, terlihat bahwa proses impelementasi manajemen kualitas akan dimulai dari tahap introduksi, kemudian tahap adopsi, dan selanjutnya tahap adaptasi.

Tahap implementasi merupakan fase di mana perusahaan menerapkan metode Six Sigma untuk perbaikan berkelanjutan (continuous improvement) di seluruh level bisnis perusahaan. Pada tahap ini, faktor yang mendukung proses implementasi Six Sigma di perusahaan: 1) Komitmen pimpinan. Pada tahap ini, pimpinan harus membuktikan komitmennya dengan turut terlibat dalam proses perbaikan berkelanjutan dan harus konsisten menjalankan apa yang dikomunikasikan. 2) Struktur organisasi Six Sigma. Struktur organisasi Six Sigma yang terdiri dari agen-agen Six Sigma yang sesuai dengan proses bisnis perusahaan mendukung penerapan Six Sigma pada tahap implementasi. Apabila perusahaan bermaksud untuk mengimplementasikan Six Sigma pada keseluruhan proses bisnisnya, maka agen Six Sigma dalam struktur organisasi Six Sigma harus sesuai dengan proses bisnis perusahaan. Black Belt Manufaktur mendukung proyek Six Sigma di divisi Manufaktur, dan Black Belt komersil mendukung proyek Six Sigma di Divisi Komersil atau Divisi Non Manufaktur. 3) Kebijakan Perusahaan. Kebijakan perusahaan yang sejalan dengan manajemen kualitas Six Sigma, antara lain kebijakan staf yang mewajibkan staf perusahaan untuk terlibat dalam proses perbaikan dengan mengerjakan proyek Six Sigma mendukung pada tahap implementasi. Hal ini merupakan mekanisme yang mendukung anggota perusahaan untuk menjalankan perbaikan secara berkelanjutan. 4) Manajemen Personalia. Perusahaan harus menyadari bahwa karyawan adalah aset perusahaan yang menjadi kunci keberhasilan perusahaan jangka panjang, sehingga keterlibatan mereka menjadi faktor pendukung implementasi Six Sigma. Mekanisme yang dapat mendukung proses implementasi pada tahap ini adalah mekanisme paksaan (coercive mechanism) dan mekanisme promosi (promotion mechamism). Mekanisme paksaan yang dapat mendukung berjalannya proyek Six Sigma sebagai upaya perbaikan proses antara lain penilaian, penghargaan, dan jenjang karir karyawan yang dihubungkan dengan Six Sigma. Mekanisme

\begin{tabular}{|c|c|c|}
\hline $\begin{array}{c}\text { Introduksi: } \\
\text { Pemahaman Konsep } \\
\text { dan Prinsip }\end{array}$ & $\begin{array}{l}\text { Adopsi: } \\
\text { Persiapan dan } \\
\text { Perencanaan }\end{array}$ & \rangle $\begin{array}{c}\text { Adaptasi: } \\
\text { Monitoring, Penyesuaian, } \\
\text { dan Peningkatan }\end{array}$ \\
\hline
\end{tabular}

Gambar 1. Model Penelitian 
promosi yang mendukung antara lain melakukan kegiatan cerdas cermat, kuis, kompetisi, dan buletin Six Sigma yang sifatnya memotivasi staf untuk terlibat dalam proyek Six Sigma. 5) Manajemen Proses. Perbaikan proses dalam strategi Six Sigma dilakukan dengan prosedur DMAIC. Diperlukan konsistensi dalam menjalankan setiap langkah pada DMAIC untuk mendukung pelaksanaan proyek Six Sigma, dan karena proyek Six Sigma dilakukan dalam tim, maka hal kedua yang mendukung tahap implementasi terkait dengan manajemen proses Six Sigma adalah kerja sama tim. 6) Manajemen Sumber Daya. Pengelolaan sumber daya diperlukan untuk mendukung manajemen proses. Faktor yang mendukung tahap implementasi adalah dana untuk mendukung proyek perbaikan yang dijalankan oleh tim. Informasi juga menjadi faktor pendukung dalam menjalankan proyek Six Sigma, di mana bertukar informasi merupakan pendukung proses pembelajaran anggota perusahaan. 7) Proses Pembelajaran. Pada tahap ini, pembelajaran perusahaan harus tetap berjalan untuk mendukung perbaikan yang berkesinambungan. Pertemuan reguler untuk mempresentasikan proyek Six Sigma yang akan dan sedang berjalan mendukung proses pembelajaran anggota perusahaan dalam mengimplementasikan Six Sigma.

Sementara itu, variabel dan atribut yang digunakan untuk mengkaji proses implementasi manajemen kualitas disarikan pada Tabel 1. Variabel penelitian tersebut terdiri atas variabel introduksi, adopsi, dan adaptasi.

Tabel 1. Variabel dan Atribut

\begin{tabular}{ll}
\hline \multicolumn{1}{c}{ Variabel } & \multicolumn{1}{c}{ Atribut } \\
\hline Introduksi & $\begin{array}{l}\text { Motivasi pengembangan manajemen kualitas, } \\
\text { pengaruh pasar, dan kebutuhan memenuhi } \\
\text { standar spesifikasi. }\end{array}$ \\
Adopsi dan & $\begin{array}{l}\text { Aksi, keputusan dan dampak terhadap } \\
\text { struktur organisasi, sistem, prosedur, } \\
\text { pendidikan dan pelatihan, standardisasi, dan } \\
\text { sertifikasi. }\end{array}$ \\
\hline
\end{tabular}

Penelitian ini menggunakan strategi penelitian studi kasus (case study). Studi kasus ini dilaksanakan di perusahaan $\mathrm{X}$ yang merupakan perusahaan yang sudah mampu ekspor dan nilai penjualan yang cenderung meningkat. Pengumpulan data dilakukan dari bulan Januari 2010 sampai dengan bulan Maret 2010. Penelitian ini menggunakan multiple source of evidence yang bersumber dari wawancara, studi arsip atau dokumen, dan observasi langsung. Wawancara digunakan sebagai sumber data utama untuk memperoleh gambaran yang menyeluruh berkaitan dengan proses implementasi manajemen kualitas di perusahaan $\mathrm{X}$.

\section{HASIL DAN PEMBAHASAN}

Pengakuan atas kualitas produk, kemampuan untuk melakukan ekspor ke berbagai negara, dan tuntutan dari para pelanggan untuk sertifikasi penjaminan kualitas merupakan kejadiankejadian signifikan yang berpengaruh terhadap pengembangan manajemen kualitas di Perusahaan X. Kejadian-kejadian ini memiliki implikasi yang kritis terhadap tindakan dan keputusan yang diambil oleh manajemen Perusahaan X.

Perusahaan X ini berdiri pada tahun 1978 dengan prioritas untuk memenuhi permintaan pelanggan pada skala domestik, yaitu untuk di daerah Bandung saja. Perusahaan X ini terus berkembang, sehingga dalam kurun waktu 1978 sampai dengan 1980 telah mampu membangun kepercayaan dari pelanggannya karena memiliki kualitas produk yang baik. Berdasarkan informasi dari pemilik Perusahaan $\mathrm{X}$ ini, mulai tahun 1980 penjualan mengalami peningkatan yang berarti, sehingga keputusan yang diambil manajemen pada saat itu adalah melakukan pembelian beberapa mesin produksi dari Jepang.

Momen yang paling krusial yang dilakukan oleh Perusahaan X terjadi pada tahun 1983, di mana pada saat itu Perusahaan X mulai merintis untuk melakukan ekspor produknya ke beberapa negara di antaranya ke Hongkong, Amerika, dan Jepang. Ketiga negara ini akhirnya menjadi pelanggan tetap. Ekspor produk pun mengalami peningkatan selama kurun waktu 6 tahun. Dengan kondisi seperti ini dapat dikatakan bahwa Perusahaan X ini memiliki kemampuan untuk membuat produk dengan kualitas standar internasional. Keputusan pihak manajemen yang diambil dengan adanya peningkatan kemampuan dalam membuat produk dengan kualitas standar internasional adalah dengan meningkatkan secara terus menerus upaya-upaya intensif dalam peningkatan kualitas produk dan proses agar produk yang dihasilkan benar-benar sesuai dengan kebutuhan pasar.

Meskipun Perusahaan X telah mampu membuat produk dengan kualitas standar internasional, tetapi dalam perjalanannya yaitu pada akhir tahun 1990 terdapat tuntutan dari pelanggan di luar negeri agar Perusahaan X memiliki sertifikasi penjaminan kualitas seperti ISO. Permintaan para pelanggan akan hal ini tidak terlalu mempengaruhi terhadap penjualan Perusahaan X, akan tetapi adanya persepsi dari pelanggan bahwa kualitas produk yang dihasilkan oleh Perusahaan X masih rendah karena belum adanya sistem manajemen kualitas yang terstruktur dan terorganisasi. Dengan kondisi seperti ini, sistem penjaminan kualitas menjadi kebutuhan mendesak bagi Perusahaan X. Rapat pimpinan pun dilakukan untuk membahas hal ini, 
dan keputusannya adalah perlu adanya program pengembangan sertifikasi penjaminan kualitas di Perusahaan X.

Selama 2 (dua) tahun yaitu pada tahun 1996 sampai dengan 1997, Perusahaan X melakukan perencanaan untuk pengajuan sertifikasi penjaminan kualitas. Rencana ini langsung disampaikan kepada pada para pelanggan dan respon dari para pelanggan sangat positif, terbukti dengan adanya dukungan moral yang disampaikan para pelanggan kepada Perusahaan X. Keputusan yang diambil oleh Direktur Perusahaan $\mathrm{X}$ adalah pengembangan sistem manajemen kualitas ISO 9001 : 1994. Dalam mendukung rencana sertifikasi ini dilakukan beberapa upaya, yaitu: 1) pembentukan steering comitte, 2) pengembangan kapabilitas SDM, 3) konsultasi dengan lembaga lain, dan 4) pembuatan quality manual dan quality procedure.

Pertama, penunjukkan steering comitte dilakukan oleh Direktur Perusahaan X beranggotakan 9 (sembilan) karyawan yang berasal dari bagian yang berbeda di perusahaan. Tugas kesembilan karyawan ini dikirim perusahaan untuk mempelajari masalah ISO, mendapatkan pelatihan mengenai ISO, dan memahami semua yang berhubungan dengan ISO. Kedua, pengembangan kapabilitas SDM dilakukan dengan mengikutsertakan steering comitte untuk mengikuti pelatihan tentang ISO yang mencakup persyaratan perusahaan untuk menerapkan ISO, prosedur ISO, membuat dokumen sesuai dengan standar ISO, bagaimana cara mengendalikan dokumen dalam perusahaan sampai pada bagaimana cara melakukan audit. Ketiga, melakukan konsultasi dengan lembaga lain yaitu Balai Besar Tekstil (BBT) yang bertugas untuk membimbing perusahaan dalam menerapkan ISO. Konsultan ini dikontrak oleh Perusahaan X sampai mendapatkan sertifikasi ISO. Keempat, membuat rancangan quality manual dan procedure yang dilakukan oleh steering comitte.

Berkaitan dengan prosedur, Perusahaan X telah berhasil membuat beberapa prosedur di antaranya adalah prosedur pengendalian dokumen, pengendalian rekaman mutu, pengadaan SDM, pengembangan SDM, pengendalian saran dan prasarana, perencanaan dan pengendalian produksi, perawatan mesin, pengendalian produk cacat, pengendalian alat ukur dan alat uji, proses pembelian, proses penjualan, inspeksi dan pengujian, penetapan sasaran dan standar mutu, proses audit mutu internal, tindakan perbaikan, dan tindakan pencegahan.

Dalam waktu beberapa bulan, dokumen-dokumen perusahaan telah selesai dibuat dan perusahaan pun siap untuk mengajukan sertifikasi. Setelah melakukan pengajuan, maka perusahaan pun diperiksa oleh auditor ekstenal. Namun, pada saat itu, baru $80 \%$ aktivitas yang diperiksa karena sisanya masih belum sesuai dan harus dilakukan perbaikan. Setelah selesai diperbaiki dan sesuai dengan persyaratan, maka pada tahun 1998 Perusahaan $\mathrm{X}$ telah menjadi sebuah perusahaan yang memiliki sistem penjaminan kualitas. Hal ini ditunjukkan dengan pada tahun tersebut Perusahaan X telah tersertifikasi dengan sistem penjaminan kualitas ISO 9001 : 1994. Lembaga yang memberikan sertifikasi ISO 1991 : 1994 adalah SAI Global Certification Service.

Sebagai organisasi yang telah memiliki sertifikasi ISO 9001 : 1994, Perusahaan X terus melakukan peningkatan kualitas produk dan proses secara berkesinambungan, terutama berkaitan dengan program reduksi produk cacat. Untuk keberhasilan program ini diperlukan keterlibatan unsur pimpinan dan karyawan. Pimpinan terus memberikan dukungan moral bagi karyawan Perusahaan X untuk melakukan peningkatan kualitas secara kesinambungan, sehingga menunjukkan adanya komitmen pimpinan terhadap peningkatan kualitas. Keputusan yang diambil berkaitan dengan hal ini adalah perlunya pengelolaan kualitas yang bertumpu pada siklus PDCA (plan, do, check, action). Upaya-upaya yang dilakukan adalah pengembangan program Gugus Kendali Mutu (GKM) yang beranggotakan 10 (sepuluh) orang, bertujuan untuk memecahkan masalah kecacatan produk yang sering muncul di Perusahaan X.

Program GKM ini bertugas untuk menemukan sumber-sumber yang mengakibatkan kecacatan produk dan kemudian diusulkan perbaikan dalam mereduksi kecacatan produk tersebut. Dengan adanya program GKM ini, kecacatan produk dapat direduksi sebanyak 60\%. Sayang sekali program GKM ini tidak berlanjut, dan hanya sampai dengan akhir tahun 2002. Berdasarkan informasi dari kepala bagian quality assurance pihak perusahaan telah merasa puas dengan adanya reduksi kecacatan $60 \%$,jadi pimpinan puncak memutuskan untuk menghentikan sementara program GKM ini. Selain itu, kesadaran pimpinan dan karyawan terhadap peningkatan terhadap kualitas secara berkesinambungan terus ditingkatkan. Upaya yang dilakukan berkaitan dengan peningkatan kesadaran ini dilakukan melalui pelatihan rutin dan sosialisasi pentingnya peningkatan kualitas melalui rapat-rapat.

Setelah tiga tahun berlalu, tepatnya tahun 2001, Perusahaan X melakukan pendaftaran untuk resertifikasi ISO ke SAI Global Certification Service. Tidak hanya resertifikasi, melainkan Perusahaan X melakukan upgrading sistem manajemen kualitas ke ISO versi 9001 : 2000. 


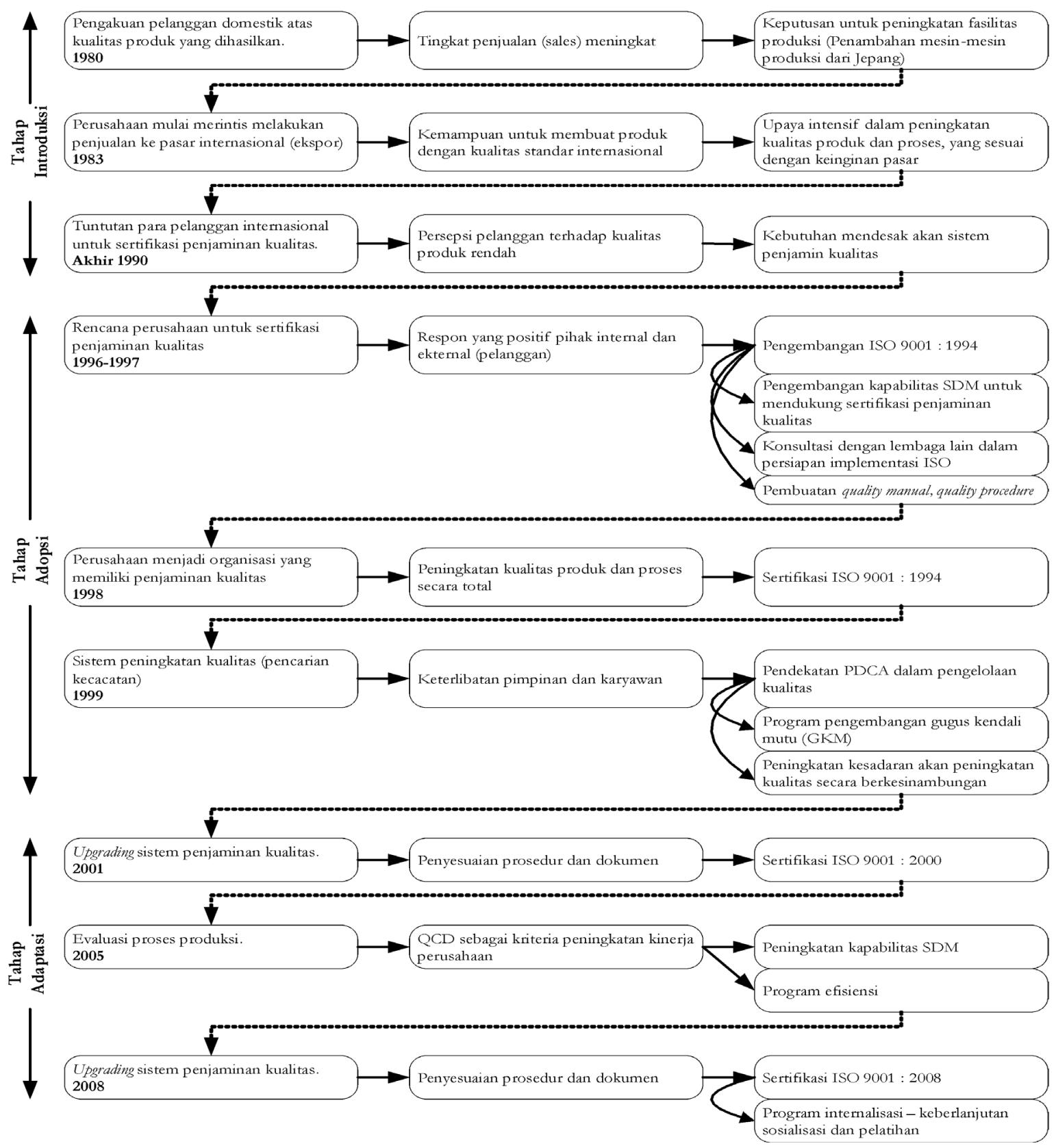

Gambar 2. Proses Implemententasi Manajemen Kualitas di Perusahaan X

Tabel 2. Kejadian Signifikan dan Respon

\begin{tabular}{|c|c|c|}
\hline & Isu Non Teknis & Isu Teknis \\
\hline Kejadian & - Perusahaan melakukan ekspor & - Pengakuan atas kualitas produk \\
\hline Signifikan & $\begin{array}{l}\text { - Tuntutan pelanggan akan sistem penjaminan } \\
\text { kualitas } \\
\text { - Evaluasi proses produksi }\end{array}$ & $\begin{array}{l}\text { - Sistem peningkatan kualitas } \\
\text { - Rencana sertifikasi sistem penjaminan kualitas } \\
\text { - Resertifikasi dan upgrading sistem penjaminan kualitas }\end{array}$ \\
\hline \multirow[t]{2}{*}{ Respon } & Keputusan Strategis & \\
\hline & $\begin{array}{l}\text { - Peningkatan fasilitas produksi } \\
\text { - Peningakatan kapabilitas SDM }\end{array}$ & $\begin{array}{l}\text { - Pengembangan sistem penjaminan kualitas } \\
\text { - PDCA dalam pengelolaan kualitas } \\
\text { - Program efisiensi } \\
\text { - Sertifikasi ISO } \\
\text { - Peningkatan kualitas produk dan proses }\end{array}$ \\
\hline
\end{tabular}


Untuk keperluan upgrading ini dituntut penyesuaian prosedur dan dokumen berdasarkan kebutuhan yang dipersyaratkan dalam sistem manajemen kualitas ISO versi 9001 : 2000. Berkat pengalaman dalam mengimplementasikan ISO versi 9001 : 1994 dan dibantu oleh BBT maka penyesuaian prosedur dan dokumen dapat dilakukan dengan baik, sehingga setelah dilakukan audit ekternal oleh SAI Global Certification Service. Pada akhir tahun 2001 Perusahaan X memperoleh sertifikasi sekaligus upgrading ke ISO 9001 : 2000. ISO versi ini digunakan oleh Perusahaan X sampai dengan tahun 2007, dan dalam perjalanannya telah dilakukan resertifikasi untuk ISO versi 9001 : 2000 ini pada tahun 2004.

Pada tahun 2005, ongkos produksi meningkat secara signifikan karena harga bahan baku yang diimpor mengalami kenaikan. Dalam keadaan seperti ini, Perusahaan X melakukan evaluasi terhadap proses produksi. Efektivitas proses produksi yang dikembangkan diukur dengan kriteria mampu meningkatkan kualitas produk, pengurangan ongkos, dan pengiriman tepat waktu. Keputusan yang dilakukan oleh Perusahaan X adalah melakukan peningkatan kapabilitas SDM melalui program pelatihan dan dicanangkannya program efisiensi.

Pada akhir tahun 2007, Perusahaan X melakukan resertifikasi ISO yang ketiga sekaligus melakukan upgrading dari ISO 9001 : 2000 ke versi ISO 9001 : 2008. Seperti yang telah dilakukan upgrading sebelumnya, maka diperlukan penyesuaian prosedur dan dokumen dan Perusahaan X tidak mengalami kesulitan yang berarti dalam upgrading ISO ke versi 9001 : 2008, karena berkat pengalaman implementasi ISO di dua versi yang berbeda sebelumnya. Pada awal tahun 2008, setelah dilakukan audit ekternal oleh SAI Global Certification Service maka Perusahaan X dinyatakan lulus untuk memiliki sertifikasi ISO 9001 : 2008. Dengan adanya upgrading sistem manajemen kualitas ke ISO 9001 : 2008, secara terus-menerus Perusahaan $\mathrm{X}$ melakukan proses sosialisasi dan pelatihan-pelatiahan berkaitan dengan pemahaman dan implementasi ISO 9001 : 2008.

Ringkasan mengenai kronologis proses ini ditunjukkan pada Gambar 2. Pada Gambar 2 tersebut diberikan gambaran bagaimana sistem dan praktik manajemen kualitas terbangun di Perusahaan X yang dimulai tahap introduksi, adopsi, hingga adaptasi.

Berbagai tindakan dalam implementasi manajemen kualitas diinisasi oleh kejadian-kejadian signifikan yang mendorong pihak manajemen untuk mengambil beberapa keputusan. Beberapa kejadian signifikan, yang dilihat sebagai reaksi awal dan beberapa keputusan manajemen terhadap kejadian signifikan dari proses implementasi manajemen kualitas tersebut disarikan pada Tabel 2.

Kejadian-kejadian signifikan merupakan dorongan ekternal, di mana dalam beberapa kasus berasal dari kejadian yang tidak terkontrol dan terkoordinasi. Perusahaan menganggap bahwa dorongan ini merupakan pengaruh yang kritis, baik menyangkut isu non teknis maupun isu teknis, dan memotivasi perusahaan untuk bereaksi. Sebagai reaksi terhadap kejadian-kejadian signifikan yang berasal dari lingkungan eksternal tersebut, mendorong pihak manajemen Perusahaan X untuk mengambil tindakan berupa pengambilan keputusan yang bersifat strategis.

\section{SIMPULAN}

Berdasarkan penelitian yang telah dilakukan, dapat diambil kesimpulan bahwa Perusahaan X telah melaksanakan tahapan-tahapan dalam implementasi manajemen kualitas dalam waktu yang tidak sebentar dan telah dilakukan dengan baik, misalnya dengan melakukannya sertifikasi sistem penjaminan kualitas (ISO), resertifikasi dan upgrading sistem penjaminan kualitas ISO. Proses impelementasi manajemen kualitas yang dilakukan oleh Perusahaan X, pada intinya bertujuan meningkatkan kepuasan pelanggan, baik domestik dan luar negeri, didukung oleh adanya peningkatan kualitas secara berkelanjutan, dan dalam praktiknya melibatkan semua orang (pimpinan dan karyawan).

\section{DAFTAR PUSTAKA}

Damayanti, R.W. 2005. Analisis Faktor-Faktor Pendukung Implementasi Six Sigma, Tesis Magister, Program Studi Teknik dan Manajemen Industri, ITB, Bandung.

Goetsch, D.L., S.B. Davis. 2006. Quality Management: Introduction to Total Quality Management for Production, Processing, and Services. Pearson Prentice Hall. New Jersey. pp. 6.

Hansson, J. 2003. "Total Quality Management Aspect of Implementation and Performance", Doctoral Thesis. Lulea University of Technology.

Hellsten, U., B. Klefsjo. 2000. TQM as a Management System Consisting of Values, Techniques, and Tools. TQM Magazine. Vol 12 No. 4, pp. 238-244.

Irianto, D. 2005. Quality Managemen Implementation: A Multiple Case Study in Indonesian Manufacturing Firm, PhD Dissertation, University of Twente, Enschede.

Oakland, J.S. 1995. Total Quality Management, Butterworth-Heinemann. p. 411. 
Rampersad, H.K. 2005. Managing Total Qualiy. Tata McGraw-Hill Publishing Company Limited. New Delhi, p. 18.

Shrivastava, R.L., R.P. Mohanty, R.R. Lakhes. 2006. Linkages Between Total Quality Management and Organisational Performance: An Empirical Study for Indian Industry. Production Planning and Control. Vol 17 No. l, pp. 13-3.
Taylor, W.A. 1996. Sectoral Differences in Total Quality Management Implementation: the influence of management mind-set, Total Quality Management. 7(3). pp. 235-248.

Zhang, Z. 2000. Implementation of Total Quality Management: An Empirical Study of Chinese Manufacturing Firm. PhD Dissertation. University of Groningen. The Netherlands. 